Веретенко Т., Ярмоленко К. Соціально-пелагогічна профілактика інтернет-залежності...

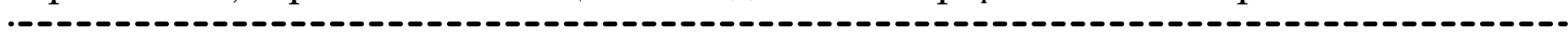

УДК 37.013.42

Тетяна ВЕРЕТЕНКО,

orcid.org/0000-0002-7184-3764

кандидат педагогічних наук, професор,

завідувач кафедри соиіальної педагогіки і соиіальної роботи Інституту людини Київського університету імені Бориса Грінченка

(Київ, Україна) t.veretenko@kubg.edu.ua

Крістіна ЯРМОЛЕНКО,

orcid.org/0000-0001-7357-9621

магістрант спеціальності «Соціальна педагогіка»

Інституту людини Київського університету імені Бориса Грінченка

(Київ, Україна) kyyarmolenko.il16@kubg.edu.ua

\title{
СОЦІАЛЬНО-ПЕДАГОГІЧНА ПРОФІЛАКТИКА ІНТЕРНЕТ-ЗАЛЕЖНОСТІ СТАРШОКЛАСНИКІВ
}

\begin{abstract}
У сучасному світі прогрес у сфері поширення та розвитку інформачійно-комунікачійних технологій набирає стрімких обертів. Активне користування новими засобами телекомунікачії, зокрема Інтернетом як глобальним інформачійним ресурсом, приваблює суспільство незалежно від віку, освіти та сочіального статусу. Необмежене використання комп 'ютерних технологій та Інтернету перетворилося на загрозу повноиінному розвитку особистості, ї̈ психічному та фізичному здоров'ю.

Інтернет є доволі привабливим і простим способом відходу від реальності, гарним засобом сховатися від різноманітних проблем для тих, хто страждає від негараздів у сім $і ̈$, на роботі, хто схильний до депресій. Психіатри вважсають, що че схоже на пристрасть до алкоголю чи азартних ігор і призводить не лише до того, що людина відкладає прийняття важливих рішень, але також і до зміни ї̈ особистості. Особливості віртуальної реальності такі, що користувач, який опинився в ній, «змушений» актуалізувати витіснені в підсвідомість інфантильні уявлення й поведінкові патерни. Ефект посилюється ще й тим, що це здебільшого відповідає власним психологічним потребам користувача. Інтернет-залежність - це явище, яке в останні роки набуло справді вражаючого розмаху. Особливо небезпечною вона є для дітей і підлітків, адже їм набагато складніше самостійно впоратися з потягом до онлайн-життя $і$ вчасно зупинитися. Інтернет сам по собі не є хорошим чи поганим - ие просто частина світу, який нас оточує, багато в чому корисна й потрібна. Будучи невичерпним джерелом інформачії, Інтернет приваблює дітей можливістю дізнатися й побачити все, що завгодно. Цікава до всього дитина прагне отримати якомога більше спілкування, ігор, мультфільмів, розваг, і тому багато часу проводить у віртуальному просторі, часто на шкоду реальному життю. Сочіалізацію й спілкування з однолітками дитина замінюе фактично однобоким онлайн-спілкуванням. Активним іграм на свіжому повітрі все більше дітей протиставляє мережеві ігри, далеко не завжди нешкідливі. Іноді пошук нової інформачії стає буквально нав' 'язливою ідеєю. Стариокласник має навчитися протистояти спокусі проводити час за комп 'ютером у сочіальному оточенні та за допомогою сочіального оточення, а не лише внаслідок утручання окремих фахівців. Це твердження пояснює інший принии сочіалізаџії підлітків, що мають Інтернет-залежність. Процес спілкування дитини з комп 'ютером має відбуватися без відриву від навчального прочесу та під керівнищтвом, наглядом із боку дорослих.

Тому проблема Інтернет-залежності все більше привертає увагу представників громадськості та є досить актуальною серед учених у різних країнах світу, щуо спонукає до ї̈ глибшого дослідження та пошуку ефективних шляхів боротьби із иією проблемою.

Ключові слова: Інтернет-залежність, профілактика, сочіально-педагогічна профілактика, старшокласники.
\end{abstract}

Tetiana VERETENKO, orcid.org/0000-0002- 7184-3764 Candidate of Pedagogical Sciences, Professor, Head at the Department of Social pedagogy and Social Work, Institute of Human Sciences of the Borys Grinchenko Kyiv University

(Kyiv, Ukraine) t.veretenko@kubg.edu.ua

Kristina YARMOLENKO, orcid.org/0000-0001-7357-9621 Master of specialty Social pedagogy, Institute of Human Sciences of the Borys Grinchenko Kyiv University (Kyiv, Ukraine) kyyarmolenko.il16@kubg.edu.ua

\section{SOCIO-PEDAGOGICAL PREVENTOIN OF INTERNET ADDICTION SENIOR PUPILS}

In the modern world, the progress in the field of distribution and development of informatively-communication technologies is collects swift turns. Active use of new facilities of telecommunication, especially the Internet, as a global information resource, attracts society regardless of age, education and social status. Therefore, the unlimited use of gadgets and the Internet network 
grew into the threat of valuable development of personality, its mental health. The Internet is a rather attractive and easy way to get away from reality, a good way to escape from a variety of problems for those who suffer from problems in the family, at work, prone to depression. Psychiatrists believe it is like a passion for alcohol or gambling and leads not only to the fact that a person postpones the adoption of important decisions, but also before changing her personality. Virtual features the reality is that the user who is in it, "forced" to actualize the subconsciously suppressed infantile representations and behavioral patterns The effect is also enhanced by the fact that it is mostly in line with its own psychological needs of the user Internet addiction is a phenomenon that in recent years has gained a truly spectacular scope. It is especially dangerous for children and adolescents, because it is much more difficult for them to cope with the train of online life and stop in time. The Internet itself is not good or bad-it's just part of the world that surrounds us, in many ways useful and necessary. Being an inexhaustible source of information, the Internet attracts children the opportunity to learn and see everything. It is interesting to the whole child trying to get as much as possible: communication, games, cartoons, entertainment-and therefore spends a lot of time in the virtual space, often in contrast to real life. Socializing and communicating with peers replaces practically one-way online communication. Active outdoor games are more and more children opposed to network games, which are far from always harmless. Sometimes the search for new information becomes literally an obsessive idea. Senior pupils have to learn resisting a temptation to spend time at a computer in a social environment and through social networks but not only due to the experts' intervention. This statement explains another principle of socialization of adolescents with Internet addiction. The process of juvenile communication with a computer should take place without interruption of educational process and under the guidance and supervision of adults. So, the problem of Internet addiction is attracting the attention of public authorities and is quite relevant among scholars around the world and encourages more in-depth research and the search for effective ways to overcome it.

Key words: Internet addiction, prevention, socio-pedagogical prevention, senior pupils.

Постановка проблеми. Стрімкий розвиток комп'ютерних технологій за останні роки накладає певний відбиток на розвиток особистості сучасних школярів. Бурхливий потік нової інформації, застосування комп'ютерних технологій дуже впливає на формування сучасних старшокласників. Суттєво змінюється й структура їхнього дозвілля. Разом із безсумнівним позитивним значенням НТР слід відзначити негативні наслідки цього процесу, що впливають на психічне та фізичне здоров'я старшокласників. Негативним наслідком цього процесу є явище Інтернет-залежності.

За підрахунками А. Войскунського, для подвоєння накопичених людством знань треба було 1750 років, друге подвоєння відбулося в 1900 р., а третє - до 1950 р. (тобто вже за 50 років) (Войскунский, 2000: 101). Поява інформаційного середовища, або віртуального простору, змусила вчених звернути увагу на позитивну й негативну трансформацію особистості в результаті їхньої взаємодії. Вивчення процесів впливу віртуальної реальності на навчально-виховну діяльність старшокласників $\epsilon$ актуальним і важливим науковим завданням соціально-педагогічних досліджень, оскільки воно дає адекватне розуміння дійсності та відкриває можливості для осмисленого й цілеспрямованого розвитку особистості в сучасних умовах.

Аналіз досліджень. Теоретико-методологічну основу дослідження становлять концепції соціальнопедагогічної діяльності з підлітками (Т. Алєксєєнко, О. Безпалько, Т. Веретенко, І. Звєрєва, А. Капська, Г. Лактіонова); технологій соціально-педагогічної роботи з підлітками (Р. Вайнола, Н. Заверико, І. Зайнишев, С. Коношенко, С. Холостова, Н. Чернуха), участі підлітків у житті суспільства (Ж. Петрочко, А. Річардсон, Р. Харт), профілактики Інтернет-залежності та їі психологічної корекції (А. Войськунський, М. Дрепа, Ф. Саглам, I. Розіна, А. Аветісова, О. Арестова, Л. Бабаніна, Г. Солдатова, Е. Бєлінська, А. Жичкіна, Н. Коритникова).

Мета статті - розглянути та проаналізувати чинники, які зумовлюють виникнення й розвиток Інтернет-залежності, виявити основні детермінанти для розроблення системи профілактичних заходів попередження iї негативних наслідків.

Виклад основного матеріалу. У період розквіту науково-технічного прогресу людство максимально використовує його блага для покращення якості життя. Одним із беззаперечних великих винаходів є глобальна комп'ютерна мережа - Інтернет. Від моменту створення всього за 5 років він став невід'ємною частиною життя мільйонів людей. Завдяки Всесвітній павутині ми маємо доступ до будь-якої інформації, можемо безкоштовно листуватися 3 друзями в найвіддаленіших куточках світу в режимі реального часу. Та чи насправді все так безхмарно, як здається на перший погляд?

Обговорення феномена залежності від Інтернету почалося з 1994 р., коли доктор психології Пітсбургського університету США Кімберлі Янг розробила та розмістила на веб-сайті спеціальний тест-опитувальник, в якому взяли участь 500 Інтернет-користувачів. Результати тесту були приголомшливими: 400 осіб виявилися Інтернет-залежними. Тому К. Янг розробила класифікацію основних видів Інтернет-залежності:

1) комп'ютерна залежність (computer addiction): обсесивна пристрасть до роботи за комп'ютером (програмування, ігри чи інші види діяльності);

2) компульсивна навігація в мережі (net compulsions): компульсивний пошук інформації у віддалених базах даних; 
Веретенко Т., Ярмоленко К. Соціально-пелагогічна профілактика інтернет-залежності...

3) перевантаженість інформацією (information overload): патологічна схильність до опосередкованих Інтернетом азартних ігор, онлайн-аукціонів, електронних покупок;

4) кіберсексуальна залежність (cybersexual addiction): залежність від «кіберсексу», тобто від відвідування порнографічних сайтів, обговорення сексуальної тематики в чатах або закритих групах «для дорослих»;

5) кіберкомунікативна залежність (cyber-relational addiction): залежність від спілкування в соціальних мережах, форумах, чатах, групових іграх і телеконференціях, що може призвести до заміни реальних членів сім'ї й друзів віртуальними (Янг, 2000: 23).

Масштабне дослідження плюсів і мінусів Інтернету, проведене американськими дослідниками, виявило, що перебування в Мережі, ігри та спілкування з іншими користувачами дуже важливі й корисні для нормального розвитку старшокласників. Підсумок дослідження суперечить думці багатьох батьків і вчителів про те, що просиджування годинами в Інтернеті - це марна витрата часу. Бі-бі-сі передає, що до свого експерименту, який тривав три роки, науковці залучили більше 800 американських підлітків і їхніх батьків. Користуючись Інтернетом, підлітки одночасно освоюють ази нових технологій і підвищують рівень своєї грамотності, вважає автор оприлюдненої доповіді. Вони вчаться спілкуватися, створюють власні сторінки, обмінюються посиланнями; усе це, за словами вчених, іще 10 років тому вважалося дуже складним і доступним тільки фахівцям, а сучасна молодь робить це з легкістю.

На думку М. Снітко, у міжнародній практиці формування безпечної поведінки підлітків в Інтернет-мережі переважно здійснюється шляхом координації роботи веб-сайтів та їх змістового наповнення; створення єдиної мережі «гарячих ліній», боротьби з незаконним контентом і спамом; інформування користувачів Інтернет-мережі про особливості діяльності та ризики в Інтернет-мережі; надання допомоги підліткам і батькам у випадках потрапляння в ризики в Інтернет-мережі. Доведено, що наразі в Україні не проводиться системна профілактична робота 3 підлітками 3 метою попередження ризиків в Інтернет-мережі (Снітко, 2014: 14).

Проведене дослідження стало частиною великого проекту з вивчення цифрових ЗМІ, для якого різні американські фонди виділили 50 млн доларів. Головною його метою було з'ясувати, як діти й підлітки в окремо взятій країні спілкуються, вчаться й відпочивають у цифровому просторі. Зокрема, дослідники встановили, що між старшокласниками, які можуть необмежено користуватися Інтернетом, і тими, хто не має такої можливості, існує велика різниця в плані технічного розвитку. За словами науковців, проведені ними дослідження допоможуть переглянути й поліпшити сучасну систему освіти [8].

Експерти ухвалили рішення надати Інтернетзалежності статус психічного захворювання. Уперше Інтернет-залежність була внесена до офіційного діагностичного та класифікаційного довідника Американської психіатричної асоціації Diagnosticand Statistical Manual of Mental Disorders, який вийшов у травні 2013 р. (Руденко, 2014: 41).

Відповідно до нових діагностичних рекомендацій, Інтернет-залежною визнається людина, яка проводить у Мережі декілька годин на день і в якої спостерігався щонайменше один із симптомів залежності протягом трьох місяців:

- непереборне бажання ввійти в Інтернет;

- нездатність контролювати свій час в Інтернеті;

- розумове або фізичне виснаження;

- порушення сну чи концентрації уваги;

- дратівливість, депресія, знервованість, труднощі в спілкуванні з людьми в реальному житті.

На думку І. Бурмістрова, А. Рябцевої, Ю. Фомічової, А Шмельова, причинами віртуальної залежності старшокласників є підвищені вимоги дорослих, інформаційне перевантаження, нераціональне використання вільного часу, відсутність у батьків контакту з дитиною, дефіцит спілкування в сім'ї, занурення батьків у віртуальний світ, залежність від ровесників, а також те, що дитина залишена сама по собі.

Провівши анкетування з батьками, можемо узагальнити, що $73 \%$ опитуваних не цікавиться особистим життям своїх дітей через зайнятість, а $46 \%$ респондентів помічають за своїми дітьми ознаки нездужання, що виникають на тлі Інтернет-залежності. Дуже засмучує той факт, що $87 \%$ батьків не проводили з дітьми бесіди щодо безпечного користування Мережею. Однією з головних причин такої масової проблеми Інтернет-залежності і $є$ відсутність первинної профілактики вдома.

Узагальнюючи досвід психологів Н. Болсуновської, 3. Некрасової, Т. Оранж і А. Рябцевої, можемо окреслити рекомендації батькам щодо профілактики Інтернет-залежності дитини.

1. Особистий приклад батьків. Якщо батьки мають шкідливі звички, наприклад, тато звик кожний вечір проводити за комп'ютерними іграми й не може позбавитися цієї пристрасті, то буде складно досягти відмови дитини від ігор. Батьки мають показати дитині, що є багато цікавих і захоплюючих занять, окрім комп'ютерних ігор і телевізора. Батькам бажано організовувати вільний час дитини, сімейні захоплення. 
Дослідивши теоретичні основи залежності від Інтернету як соціального явища, на основі вищевикладеного ми розробили анкету на виявлення Інтернет-залежності серед учнів Київського вищого професійного училища швейного та перукарського мистецтва. У дослідженні брали участь 27 осіб: 15 дівчат і 12 хлопців. На основі анкетування ми можемо зробити висновки, що в $66 \%$ сімей батьки не приділяють належної уваги дітям, тому й виникає проблема Інтернет-залежності, яка чинить серйозний вплив на життя старшокласника. Проаналізувавши проблемні аспекти, можемо дати такі рекомендації батькам:

- разом робити побутові речі, щоб підготувати дитину до самостійного життя в соціумі;

- разом займатися творчою діяльністю, адже діти потребують похвали батьків;

- давати дитині можливість розвивати себе різнобічно; якщо в дитини буде можливість обирати самостійно, то вона буде займатися улюбленою справою, і часу на шкідливі звички просто не буде;

- започаткувати сімейні ритуали; таким чином у дітей розвиваються навички спілкування, вони вчаться слухати, говорити про свої проблеми, потреби, почуття, розуміти почуття батьків, навчаються співпереживанню. Такі бесіди допомагають як батькам, так і дітям дізнатися більше про внутрішній світ один одного, стати більш відкритими один до одного, краще розуміти один одного.

Доброзичливе ставлення до дитини, довірлива бесіда $з$ дитиною, за якої батьки емоційно спокійні та врівноваженні - основний шлях вирішення проблеми комп'ютерної залежності. На думку 3. Некрасової, проблема комп'ютерної залежності це насамперед проблема батьківсько-дитячих стосунків. Важливо, щоб дитина відчувала батьківську любов, відчувала, що ії люблять і приймають такою, якою вона $є$. Важливо, щоб батьки звернули увагу на власний емоційний стан, не переносили негативні емоції на своїх дітей (Некрасова, Некрасова, 2008: 101).

2. Дотримуватися режиму роботи з комп'ютером. Важливо домовитися $з$ дитиною про:

- час, який дитина може провести перед комп'ютером, телевізором (30 хв. на день для початкових класів, 1 година - для середніх класів, 2-3 години - для підлітків). Мотивувати закінчення комп'ютерної гри: «Якщо ти здатен зупинитися, то в тебе велика сила волі. Я пишаюся тобою». Бажано різко не вимикати комп'ютерну гру, а попередити дитину про певний час, який залишився до закінчення гри чи перегляду мультфільму, передачі;

- час, коли заборонено використовувати комп'ютер, телевізор: уранці перед школою; уве- чері перед виконанням домашнього завдання; перед сном (ігри збуджують, стимулюють мозок дитини, унаслідок чого може виникнути безсоння чи неспокійний сон).

Правила мають бути гнучкими: час, який відведений для ігор, мультфільмів, не повинен бути однаковим у навчальний період і на канікулах.

Необхідно також домовитися про те, в які ігри грати, які мультфільми дивитися. Комп'ютерні ігри $\epsilon$ різні: $\epsilon$ агресивні (різні «стрілялки») і розвиваючі ігри. Розвиваючі ігри стимулюють пізнавальний інтерес дитини до навколишнього світу (про життя тварин, про планети в космосі тощо), розвивають увагу, просторове мислення, пам'ять та інші психічні процеси. Саме на розвиваючих іграх потрібно зробити акцент, перемикаючи увагу дитини з небезпечного на корисне чи нейтральне.

3. Інтерес до комп'ютера в дитини має бути пізнавальним.

Не потрібно подавати дитині комп'ютер як зверхцінність, не варто, щоб гра на комп'ютері була винагородою за успіхи. Мудрі батьки намагаються, щоб інтерес дитини до комп'ютера був пізнавальним i практичним. Тоді це може стати основою навіть для майбутньої професії дитини (програміст, системний адміністратор).

4. Небезпека Інтернету. Соціальні мережі («Твіттер», «Фейсбук», «Інстаграм») є дуже популярними; 3 одного боку, там багато фільмів, музики, інформації пізнавального характеру, спілкування з друзями, 3 іншого - довірлива дитина може стати жертвою педофілів, крадіїв тощо. Потрібно пояснити дитині таке:

- викладати свою адресу в Інтернеті не варто;

- фото незнайомих людей, які пропонують віртуальну дружбу, може бути несправжнє, тому не варто давати свою адресу, номер телефону й розповідати подробиці свого життя;

- потрібно попередити батьків перед тим, як йти на зустріч із «віртуальним другом».

Отже, потрібно вчити дітей бути обережними в Інтернеті.

У зв'язку зі зростаючим впливом засобів масової інформації на соціалізацію дітей актуальними стають проблеми визначення позиції педагогів у роботі 3 дітьми, міри їхнього втручання в процес освоєння дітьми навколишнього світу за допомогою засобів інформації.

Провівши анонімне анкетування 3 учителями в загальноосвітньому закладі, можемо зробити висновки, що нині проблема Інтернет-залежності старшокласників $є$ нагальним питанням, яке вимагає втручання як батьків, так і школи,тому ми розробили такі рекомендації учителям: 
Веретенко Т., Ярмоленко К. Соціально-пелагогічна профілактика інтернет-залежності...

1) слідкувати за учнями, щоб вони використовувати ПК лише в навчальних і пізнавальних цілях у навчальному закладі;

2) проводити профілактичні заходи для батьків і дітей задля засвоєння правил безпечної поведінки в Мережі;

3) контролювати дотримання регламенту користування особистими засобами комунікації й особистою комп'ютерною технікою під час навчального процесу.

Багато старшокласників не знають правил безпечної поведінки в Мережі, недостатньо дбають про своє здоров'я, проводячи за комп'ютером багато часу. Науковцями T. Джішкаріані, I. Кокаревим із метою формування правильного уявлення про користування Інтернетом у дітей і їхніх батьків була підібрана тематика бесід для класних годин, батьківських зборів про користь і небезпеку Інтернету для здоров'я. Проведення класних годин, батьківських зборів передбачає використання таких методів: лекція-бесіда, бесіда, дискусія, показ презентацій і фільмів (Рябцева, 2012: 35-40).
Старшокласнику неможливо заборонити виходити в Інтернет, але запобігти негативним наслідкам нерозумного користування необхідно, а для цього потрібно навчити його культурі безпечної поведінки в Мережі. Основним змістом профілактичної роботи $\epsilon$ привчання дитини до комп'ютера для роботи, а не для гри, також дитина повинна знати правила безпечного користування Інтернетом. Для задоволення важливих для дитини потреб у любові, увазі, прийнятті, довірі до оточуючого світу батькам потрібно цікавитися життям дитини, проводити 3 нею час, рахуватися 3 iї індивідуальністю, цінувати та поважати ії особистість, залучати до різних видів діяльності (рухові ігри, спортивні секції, танцювальні та музичні гуртки, подорожі тощо). Сприятлива атмосфера в сім'ї знижує потребу дитини в комп'ютерних іграх та Інтернеті.

Висновки. Таким чином, здійснивши дослідження, ми можемо зробити висновок, що сьогодні серед старшокласників має місце проблема Інтернет-залежності. Тому актуальним вирішенням цієї проблеми є розроблення тренінгу для учнів із метою мінімізувати негативний вплив Інтернету.

\section{СПИСОК ВИКОРИСТАНИХ ДЖЕРЕЛ}

1. Болсуновская Н. Ребенок и Интернет: новые запросы к психологу. Школьный психолог. Москва: Издат. дом «Первое сентября». 2012. № 6. С. 49-51.

2. Войскунский А. Феномен зависимости от Интернета. Москва: [б. в.] , 2000. С. 100-131.

3. Некрасова 3., Некрасова Н. Как оттащить ребенка от компьютера и что потом с ним делать. Киев: София, 2008. 125 с.

4. Оранж Т. Медиадиета для детей. Руководство для родителей: как преодолеть зависимость от телевизора и компьютерных игр. Москва: Диля, 2007. 272 с.

5. Руденко І. Година психології на батьківських зборах. Черкаси : ОІПОПП, 2014. 84 с.

6. Рябцева А. Компьютерные игры в жизни подростка. Москва, 2012. № 7. С. 35-40.

7. Снітко М. Соціально-педагогічні умови формування у підлітків безпечної поведінки в Інтернет-мережі. Київ, 2014. 22 c.

8. Уніан. Інтернет важливий і корисний для нормального розвитку підлітків. URL: https://www.unian.ua/ science/165053-internet.

9. Янг К. Диагноз - Интернет-зависимость. Волгоград: Мир Интернет. № 2, 2000. С. 24-29.

\section{REFERENCES}

1. Bolsunovskaya N. Rebenok i Internet: novyye zaprosy k psikhologu [Child and the Internet: new requests to a psychologist]. Shkol'nyy psikholog: Izdat. dom «Pervoye sentyabrya», Moskva, 2012. № 6. Pp. 49-51 [in Russian].

2. Voyskunskiy A. Fenomen zavisimosti ot Interneta. [The phenomenon of dependence on the Internet]. Moskva, 2000. Pp. 100-131 [in Russian]

3. Nekrasova Z., Nekrasova N. Kak ottashchit' rebenka ot komp'yutera i chto potom s nim delat' [How to pull back a child away from the computer and then what to do with it]. Kiev: Sofiya, 2008. 125 p. [in Russian]

4. Oranzh T. Mediadiyeta dlya detey. Rukovodstvo dlya roditeley: kak preodolet' zavisimost' ot televizora i komp'yuternykh igr [Media kit for children. Guide for parents: how to overcome dependence on television and computer games]. Moskva: Dilya, 2007. 272 p. [in Russian].

5. Rudenko I. Godina psikhologiyi na bat'kivs'kikh zborakh [Hour of psychology at parent's meeting]. Cherkasi: OIPOPP, 2014. 84 p. [in Ukrainian]

6. Ryabtseva A. Komp’yuternyye igry v zhizni podrostka [Computer games in the life of a teenager]. Moskva, 2012. № 7 . Pp. 35-40. [in Russian]

7. Snitko M. Sotsialno-pedahohichni umovy formuvannia u pidlitkiv bezpechnoi povedinky v internet-merezhi [Sociopedagogical conditions for the formation of safe behavior in adolescents on the Internet]. Kyiv, 2014. 22 p. [in Ukrainian].

8. Unian. Internet vazhlyvyi i korysnyi dlia normalnoho rozvytku pidlitkiv [The Internet is important and useful for the normal development of adolescents]. URL: https://www.unian.ua/science/165053-internet [in Ukrainian]

9. Yanh K. Dyahnoz - Internet-zavysymost. [Diagnosis - Internet addiction]. Volhohrad: Myr Ynternet. № 2. 2000 Pp. 24-29 [in Russian]

Статтю подано до редакиії 04.05.2018 p. 